\title{
Liver-expressed antimicrobial peptide 2 antagonizes the effect of ghrelin in rodents
}

\author{
Md Nurul Islam,*, Yuichiro Mita1,2,* , Keisuke Maruyama1', Ryota Tanida1,3, Weidong Zhang1, Hideyuki Sakoda1 and \\ Masamitsu Nakazato1,4
}

'Division of Neurology, Respirology, Endocrinology and Metabolism, Department of Internal Medicine, Faculty of Medicine, University of Miyazaki, Miyazaki, Japan

${ }^{2}$ Systems Life Sciences Laboratory, Department of Medical Life Systems, Faculty of Life and Medical Sciences, Doshisha University, Kyoto, Japan 3Department of Sports and Fitness, Faculty of Wellness, Shigakkan University, Aichi, Japan

${ }^{4}$ CREST (Japan) Agency for Medical Research and Development (A-MED) 1-7-1 Otemachi, Tokyo, Japan

Correspondence should be addressed to M Nakazato: nakazato@med.miyazaki-u.ac.jp

*(M N Islam and Y Mita contributed equally to this work)

\begin{abstract}
Ghrelin, a stomach-derived peptide, promotes feeding and growth hormone (GH) secretion. A recent study identified liver-expressed antimicrobial peptide 2 (LEAP2) as an endogenous inhibitor of ghrelin-induced GH secretion, but the effect of LEAP2 in the brain remained unknown. In this study, we showed that intracerebroventricular (i.c.v.) administration of LEAP2 to rats suppressed central ghrelin functions including Fos expression in the hypothalamic nuclei, promotion of food intake, blood glucose elevation, and body temperature reduction. LEAP2 did not inhibit neuropeptide $Y$ (NPY)-induced food intake or des-acyl ghrelin-induced reduction in body temperature, indicating that the inhibitory effects of LEAP2 were specific for GHSR. Plasma LEAP2 levels varied according to feeding status and seemed to be dependent on the hepatic Leap2 expression. Furthermore, ghrelin suppressed the expression of hepatic Leap2 via AMPK activation. Together, these results reveal that LEAP2 inhibits central ghrelin functions and crosstalk between liver and stomach.
\end{abstract}

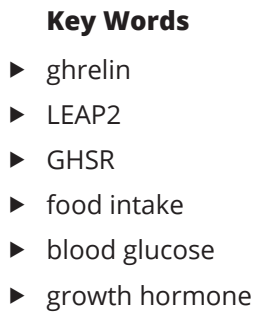

Journal of Endocrinology (2020) 244, 13-23

\section{Introduction}

Ghrelin, a 28-amino acid acylated peptide originally isolated from rat and human stomach, is involved in the regulation of energy homeostasis and growth hormone (GH) secretion (Kojima et al. 1999, Nakazato et al. 2001). The ghrelin signal is communicated to the hypothalamus, the center of regulation of feeding behavior, via the vagal afferent nerve (Yanagi et al. 2018). The activities of ghrelin are mediated through binding to the growth hormone secretagogue receptor (GHSR), a G-proteincoupled receptor (GPCR). GHSR is expressed at high levels in the hypothalamic arcuate nucleus (ARC), dorsomedial hypothalamus (DMH), ventromedial hypothalamic nucleus (VMH), and lateral hypothalamic nucleus (LH) (Mitchell et al. 2001, Zigman et al. 2006).

Liver-expressed antimicrobial peptide 2 (LEAP2), a 40 amino acid peptide, was originally isolated by comprehensive chromatographic characterization of human hemofiltrate (Krause et al. 2003). Human LEAP2 is processed from a 77 amino acid precursor by a furin-like endoprotease, and its amino acid sequence is identical to that of murine LEAP2 (Krause et al. 2003). Like many antimicrobial peptides, LEAP2 has two disulfide bonds. (c) 2020 The authors Published by Bioscientifica Ltd. Printed in Great Britain

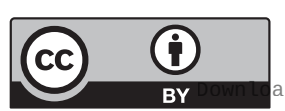

This work is licensed under a Creative Commons Attribution 4.0 International License. ded from Bioscientifica.com at 04/26/2023 05:51:12AM 
LEAP2 is the second blood-derived peptide to be discovered that is predominantly expressed in the liver and exhibits antimicrobial activity; LEAP1/hepcidin was the first (Krause et al. 2000). In high fat diet-induced obese mice, vertical sleeve gastrectomy, a common surgery for the treatment of obesity, resulted in increased expression of Leap2 in the stomach and decreased expression in the duodenum (Ge et al. 2018). LEAP2 was tested against 168 known GPCRs using PathHunter beta-arrestin enzyme fragment complementation technology (Ge et al. 2018). LEAP2 directly interacted with GHSR and inhibited GHSR activation via a noncompetitive mechanism (Ge et al. 2018). The sequence of the LEAP2 peptide is highly conserved across mammals, implying that control of GHSR by LEAP2 is a general mechanism.

Both central and peripheral administration of ghrelin induced food intake in multiple species, including humans (Nakazato et al. 2001, Wren et al. 2001), whereas systemic administration of LEAP2 to mice suppressed ghrelin-induced food intake and $\mathrm{GH}$ release (Ge et al. 2018). Therefore, we performed intracerebroventricular (i.c.v.) administration of LEAP2 in rats, and examined its suppressive effects on ghrelin-induced changes in food intake, blood glucose level, and body temperature. We also monitored plasma LEAP2 level and liver Leap2 expression under ad libitum, fasting, and re-feeding conditions. Finally, we sought to identify the mechanism of Leap2 expression in the liver.

\section{Materials and methods}

\section{Animals}

Eight-week-old male Wistar rats (Charles River Laboratories), weighing 280-300g, and 12-week-old male C57BL/6J mice, weighing around $25 \mathrm{~g}$ (Charles River Laboratories) were housed in an animal center and maintained under a 12-h/12-h light/darkness cycle (light on 08:00 and off at 20:00) at constant temperature $\left(23 \pm 1^{\circ} \mathrm{C}\right)$. Rats were fed a regular chow diet (CLEA Rodent Diet CE-2, CLEA Japan, Tokyo, Japan) and allowed free access to water. For i.c.v. operations, rats were anesthetized by i.p. injection of a mixture of three anesthetics (Domitor, $1 \mathrm{mg} / \mathrm{mL}$; midazole, $5 \mathrm{mg} / \mathrm{mL}$; vetorphale, $5 \mathrm{mg} / \mathrm{mL}$ ) in a volume of $1.5 \mathrm{~mL} / 300 \mathrm{~g}$ body weight and mounted on a stereotaxic apparatus; then, a commercial stainless steel guide cannula was implanted into the left lateral ventricle $(8.0 \mathrm{~mm}$ anterior from the interaural line, $1.5 \mathrm{~mm}$ lateral from the sagittal suture, and $3.0 \mathrm{~mm}$ ventral from the dura), according to the Rat Brain Atlas (Paxinos and Watson, Fourth Edition). After the operation, the rats were placed in individual cages and allowed to recover for at least 7 days, during which they were handled daily for acclimation. Ghrelin (human), LEAP2 (human), des-acyl ghrelin (rat), NPY, and GLP-1 were purchased from Peptide Institute (Osaka, Japan). [D-Lys ${ }^{3}$-GHRP-6, an antagonist for GHSR, was purchased from Tocris Bioscience. i.c.v. injection was carried out with an injector cannula $(27 \mathrm{G}$, $1 \mathrm{~mm}$ long from the tip of the guide cannula). Mice were anesthetized after overnight (20:00-08:00) fasting, and ghrelin was introduced through the inferior vena cava. Two hours after ghrelin administration, plasma and tissue samples were collected for LEAP2 analysis. 38-weekold GHSR-null mice (Zigman et al. 2005) which harbor a loxP-flanked transcriptional blocking cassette in both endogenous GHSR alleles were kindly provided by Dr Syu Takeda at Tokyo Medical and Dental University. In comparing study between wild-type (WT) and GHSR-null mice, 15-week-old male WT and 19-week-old GHSR-null mice were used. All animal experiments were approved by the Animal Care and Use Committee of University of Miyazaki.

\section{Peptide dose}

For i.c.v. injection, doses of peptides were as follows: ghrelin, $0.1 \mathrm{nmol}$; des-acyl ghrelin, $0.5 \mathrm{nmol}$; NPY, $1.2 \mathrm{nmol} ; \quad$ GLP-1, $\quad 0.3 \mathrm{nmol} ; \quad$ LEAP2, $1 \mathrm{nmol}$; and [D-Lys3]-GHRP-6, $20 \mathrm{nmol}$. Peptides for i.c.v. injection were dissolved in $5 \mu$ of artificial cerebrospinal fluid (aCSF) per rat. For i.p. injection, the peptide doses (otherwise stated) were as follows: ghrelin, $5 \mathrm{nmol}$; LEAP2, $15 \mathrm{nmol}$. These peptides were dissolved in $0.5 \mathrm{~mL}$ of saline per rat. For mouse experiments, ghrelin was administered intravenously (i.v.) at a dose of $60 \mathrm{nmol} / \mathrm{kg}$ body weight. For hepatocytes, peptide doses were as follows: ghrelin, 10nM; des-acyl ghrelin, 10nM in Dulbecco's Modified Eagle Medium (DMEM).

\section{Feeding experiment}

Single i.c.v. injections of ghrelin, ghrelin+LEAP2, NPY, or NPY+LEAP2 were carried out at 09:45h, and preweighed foods were supplied at 10:00 h to measure food intake at that time point. To measure dark-phase food intake, rats were deprived of food from 16:00 h to 19:45 h. Following i.c.v. injection of either LEAP2 or aCSF, rats were supplied with food at 20:00 h, and subsequent food intake was measured at several time points. To measure

This work is licensed under a Creative Commons Attribution 4.0 International License. 
fasting-induced food intake, rats were kept on a fast from 18:00h to 08:00h; following i.c.v. injection, 2-h food intake was measured. In the case of peripheral administration, LEAP2 was administered at 09:30h, and ghrelin $0.5 \mathrm{~h}$ later, after which 1 -h and 2 -h food intake were measured.

\section{Fos immunohistochemistry}

Rats ( $n=3 /$ group) received an i.c.v. injection of ghrelin or ghrelin+LEAP2. After $90 \mathrm{~min}$, they were anesthetized with a mixture of three anesthetics (Domitor, $1 \mathrm{mg} / \mathrm{mL}$; midazole, $5 \mathrm{mg} / \mathrm{mL}$; vetorphale, $5 \mathrm{mg} / \mathrm{mL}$ ) in a volume of $0.1 \mathrm{~mL} / 20 \mathrm{~g}$ body weight and transcardially perfused with ice-cold PBS and ice-cold 4\% PFA. Hypothalamic sections (thickness, $40 \mu \mathrm{m}$ ) were cut on a freezing microtome (Yamato Kohki Industrial, Saitama, Japan). For Fos immunohistochemistry, free-floating sections were blocked in blocking buffer (3\% normal serum in $0.3 \%$ PBS-T) for $60 \mathrm{~min}$, and then incubated overnight at $4^{\circ} \mathrm{C}$ with rabbit anti-c-Fos (Santa Cruz Biotechnology). After washing with PBS, the sections were incubated for $60 \mathrm{~min}$ at room temperature with Alexa Fluor 488-labeled antirabbit IgG antibody (1:500; Invitrogen). Images were visualized by confocal microscopy. Fos-positive cells were counted manually.

\section{Blood glucose and body temperature measurement}

Ghrelin or ghrelin+LEAP2 was administered i.c.v. to conscious rats at 16:00 h. After injection, blood glucose level was monitored using a glucometer (Terumo, Tokyo, Japan). Food and water were removed during the blood glucose experiment. For measurement of body temperature, rats were anesthetized by i.p. injection of urethane. i.c.v. injections were given at 16:00 h, and rectal temperature was measured with a digital thermometer (TD-300; Shibaura Electronics, Saitama, Japan).

\section{Measurements of plasma LEAP2, ghrelin, and insulin}

Blood samples were taken from anesthetized rats by cardiac puncture and collected in a tube containing aprotinin and EDTA (Wako). Samples were immediately centrifuged at $4^{\circ} \mathrm{C}$, and plasma was collected. ELISA for plasma LEAP2 was developed as previously described (Mita et al. 2017). Briefly, plasma was processed using a 10-kDa column (AmiconUltra $0.5 \mathrm{~mL}$ Centrifugation Filters; Merck Millipore), and the filtrate was subsequently used for measurement of the LEAP2 concentration.
Next, 96-well microtiter plates were coated with LEAP2 standard peptide or plasma in $100 \mathrm{mM}$ sodium bicarbonate buffer ( $\mathrm{pH}$ 9.6) and incubated overnight at $4^{\circ} \mathrm{C}$. After washing with washing buffer (PBS containg $0.05 \%$ Tween-20), non-specific binding was blocked with $1 \%$ BSA in PBS for $1 \mathrm{~h}$ at $37^{\circ} \mathrm{C}$. For detection of plasma LEAP2, rabbit polyclonal anti-LEAP2 antibody (1:3200; H075-40, Phoenix Pharmaceuticals, Burlingame, CA, USA) was added and incubated at $37^{\circ} \mathrm{C}$ for $1 \mathrm{~h}$. After washing in washing buffer, HRP-linked anti-rabbit IgG (\#7074; Cell Signaling Technology) in washing buffer containing $0.1 \%$ BSA was added, and the sample was incubated for $1 \mathrm{~h}$ at $37^{\circ} \mathrm{C}$. Finally, the plate was washed five times and TMB was added. The enzyme-substrate reaction was allowed to proceed for 5-10 min at room temperature under dark environment. The reaction was stopped by the addition of $1 \mathrm{~N} \mathrm{H}_{2} \mathrm{SO}_{4}$, and absorbance was immediately read at $450 \mathrm{~nm}$ in a 96 -well microplate reader (iMark ${ }^{\mathrm{TM}}$ microplate absorbance reader; Bio-Rad). Data demonstrating the verification of this ELISA system are provided in Supplementary Table 1 (see section on supplementary materials given at the end of this article). The inter-assay precision coefficient of variation was $<5 \%$, assay range $12-1000 \mathrm{ng} / \mathrm{mL}$. Plasma insulin was measured using a rat insulin EIA kit (Morinaga Institute of Biological Science, Yokohama, Japan). The plasma ghrelin assay was a two-site immuno-enzymatic assay requiring $100 \mu \mathrm{L}$ of plasma, performed automatically on an AIA-600II immunoassay analyzer (Tosoh, Tokyo, Japan).

\section{Measurement of $\mathrm{GH}$ release}

Primary cells were isolated from rat pituitary as previously described (Kojima et al. 1999). Primary pituitary cells were stimulated with LEAP2 $(1 \mu \mathrm{M})$ and/or ghrelin (100nM). To examine the effect of LEAP2 on GH release in vivo, saline or LEAP2 (15 nmol in $50 \mu \mathrm{L}$ saline) was introduced through the jugular vein. After $10 \mathrm{~min}$, ghrelin $(5 \mathrm{nmol})$ was administered through the jugular vein, and blood samples were taken from the tail tip at 0,15 , and $30 \mathrm{~min}$. GH was measured using the Rat/Mouse GH ELISA Kit (Millipore EMD).

\section{Extraction of mRNA and quantitative RT-PCR (qRT-PCR)}

Total mRNA from all indicated tissues was extracted using the RiboPure Kit (Life Technologies Japan). First-strand cDNA was generated by reverse transcription using the High-Capacity RNA-to-cDNA Kit (Life Technologies). qRT-PCR was performed on a Thermal Cycler Dice Real

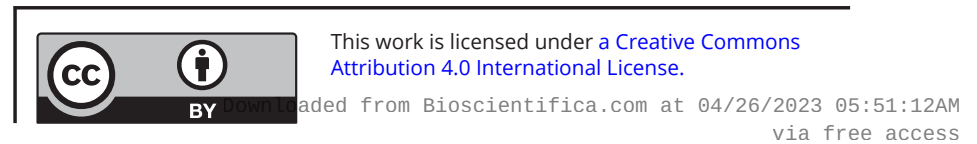


Time System II (TaKaRa Bio) using SYBR Premix Ex Taq (2X) (TaKaRa Bio) and the following primer pairs: rat Leap2, 5'-AAAGACGACGCTGTTCCCTG-3' and 5'-GAGCACTGTTGGAGGTGACTT-3'; mouse Leap2, 5'-GACCCCATTTTGGAGAGGGG-3' and 5'-GGGAACAG CGTCTTTTTCTGC-3'; rat Gapdh 5'-GGCACAGTCAAGGC TGAGAATG-3' and 5'-ATGGTGGTGAAG ACGCCAGTA-3'; mouse Gapdh 5'-TGTGTCCGT CGTGGATCTGA-3' and 5'-TTGCTGTTGAAGTCGCA GGAG-3'.

Three-dimensional digital PCR was performed on a ProFlex PCR System (Applied Biosystems) using the primer set for rat Leap2 (Rn03648192_m1).

\section{Cell culture}

Hepa1-6 cells were obtained from the American Type Culture Collection (Manassas). Hepa1-6 cells were maintained in DMEM containing 10\% heat-inactivated FBS and antibiotics (100 U/mL penicillin, $100 \mu \mathrm{g} / \mathrm{mL}$ streptomycin). Cells were cultured at $37^{\circ} \mathrm{C}$ under an atmosphere of $95 \%$ air and $5 \% \mathrm{CO}_{2}$.

Isolation of primary hepatocytes was described previously (Ariyoshi et al. 2017). Briefly, bone marrow cells were cultured in $1 \mathrm{~mL}$ Hepatocyte Culture Media (Lonza Walkersville, Walkersville, MD, USA) supplemented with $5 \% \mathrm{FBS}$ for $6 \mathrm{~h}$ in a $37^{\circ} \mathrm{C}$ incubator with $5 \% \mathrm{CO}_{2}$. One part conditioned medium was added to four parts of liver cell culture. Livers were minced to the level of $2 \mathrm{~mm}^{3}$. The pieces of liver were incubated for $30 \mathrm{~min}$ at $37^{\circ} \mathrm{C}$ with collagenaseYakult (100U/mL, Yakult Pharmaceutical, Tokyo, Japan). After collagenase treatment, the supernatant was decanted, and $5 \mathrm{~mL}$ of HGM supplemented with 10\% FBS was added; the cells were then shaken at $160 \mathrm{rpm}$ for $30 \mathrm{~min}$ at room temperature. After centrifugation at $50 \times \boldsymbol{g}$ for $2 \mathrm{~min}$, the supernatant was removed, and $5 \mathrm{~mL}$ fresh HGM was added.
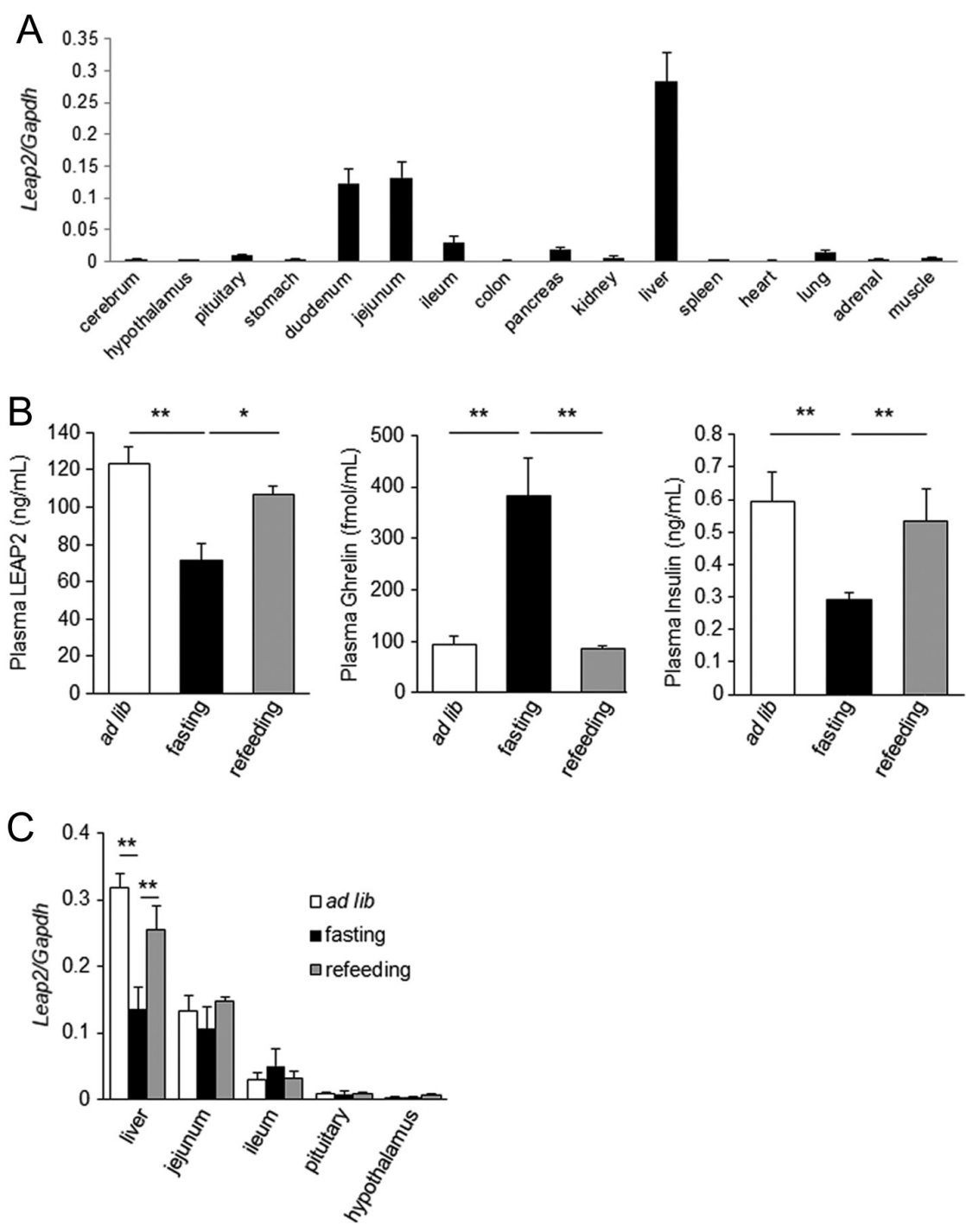

Figure 1

LEAP2 tissue distribution in rats. (A) Leap2 was highly expressed in liver and small intestine, as determined by qRT-PCR $(n=4)$. (B) Plasma LEAP2, ghrelin, and insulin levels under the indicated feeding conditions $(n=8)$ (C) Leap2 expression in liver was significantly decreased by fasting but returned to the basal level following re-feeding $(n=8)$. Bars represent means \pm S.E.M. ${ }^{*} P<0.05$, $* \star P<0.01$ https://joe.bioscientifica.com https://doi.org/10.1530/JOE-19-0102 (c) 2020 The authors Published by Bioscientifica Ltd. Printed in Great Britain
This work is licensed under a Creative Commons Attribution 4.0 International License. 


\section{Western blotting}

Samples were lysed in RIPA buffer (Nacalai Tesque) containing phosphatase inhibitor (PhosSTOP, Roche). For detection of AMPK $\alpha$ (\#2532, Cell Signaling Technology), phosphorylated AMPK $\alpha$ (Thr172) (\#2535, Cell Signaling Technology), and $\beta$-actin (A2103, Sigma), equal amounts of protein were fractionated on Tris-glycine SDS-polyacrylamide gels, subjected to electrophoresis, and transferred to a PVDF membrane (Bio-Rad). Chemiluminescence was detected using the ECL Western blot detection kit (Wako).

\section{Statistical analysis}

Student's $t$-test was used to compare two groups, and oneway ANOVA was performed for multiple comparisons. All data are presented as means \pm S.E.M. $P<0.05$ was considered to indicate significance.

\section{Results}

\section{Ghrelin regulates Leap2 mRNA expression in liver}

Leap2 mRNA was highly expressed in rat liver, as determined by qRT-PCR (Fig. 1A) and 3D digital PCR (Supplementary Fig. 1A). In mice, the Leap2 mRNA level was highest in the jejunum (Supplementary Fig. 1B), as reported previously (Ge et al. 2018). Plasma levels of LEAP2, ghrelin, and insulin were measured under various feeding conditions (Fig. 1B). Following fasting, the plasma LEAP2 level decreased, but returned to the basal level after 6 -h re-feeding. Insulin exhibited a similar pattern, whereas ghrelin behaved in the opposite manner; ghrelin levels increased with fasting and dropped after re-feeding. Leap2 mRNA expression in the liver was significantly decreased by fasting, and increased by $6 \mathrm{~h}$ re-feeding (Fig. 1C). By contrast, Leap2 mRNA expression did not alter in other organs (Fig. 1C).

Next, we investigated whether ghrelin reduced Leap2 mRNA expression in the liver. i.v. administration of ghrelin to fasted mice significantly decreased the levels of plasma LEAP2 (Fig. 2A) and Leap2 mRNA in liver (Fig. 2B). However, i.v. ghrelin did not suppress Leap2 mRNA expression in hypothalamic ARC (Fig. 2C) or pituitary (Fig. 2D). In GHSR-null mice, i.v. ghrelin did not suppress plasma LEAP2 (Fig. 2E) or Leap2 mRNA level in the liver (Fig. 2F). The plasma LEAP2 level in WT and GHSR-null mice was not changed (Fig. 2G), whereas Leap2 mRNA level in the liver of GHSR-null mice showed the tendency to
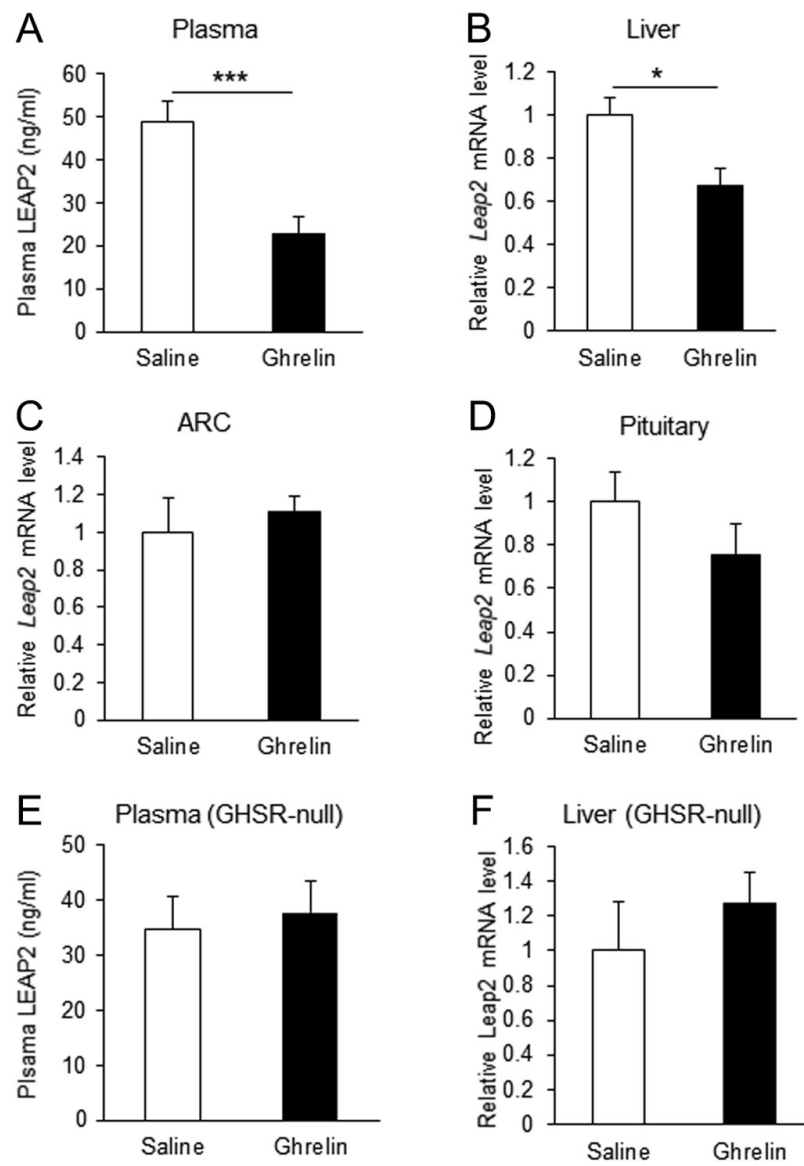

F Liver (GHSR-null)
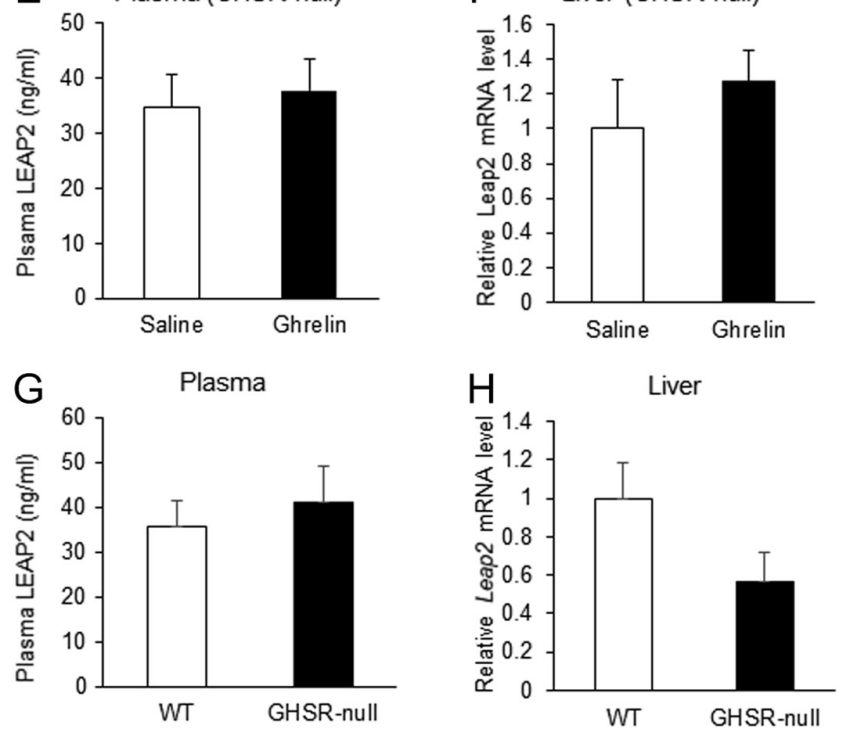

\section{Figure 2}

Ghrelin regulates LEAP2 expression in liver. i.v. administration of ghrelin to overnight-fasted mice caused a significant reduction in both plasma LEAP2 (A) and Leap2 mRNA expression in liver (B), but not in hypothalamic ARC (C) or pituitary (D) ( $n=8$ for plasma, liver and ARC, $n=4$ for pituitary). In GHSR-null mice, i.v. ghrelin did not change plasma LEAP2 (E) or Leap2 mRNA expression in liver $(\mathrm{F})(n=3)$. Comparative analysis of plasma LEAP2 $(\mathrm{G})$ and liver Leap2 mRNA expression $(\mathrm{H})$ in WT and GHSR-null mice $(n=3-6)$. Bars represent means \pm S.E.M. $* P<0.05$, *** $P<0.001$.

decrease but did not reach the significant level compared to WT mice (Fig. 2H) after a 12-h fast. Ghrelin decreased Leap2 mRNA in both primary mouse hepatocytes (Fig. 3A) and Hepa 1-6 cells (Fig. 3C). However, des-acyl ghrelin did not suppress Leap2 mRNA in Hepa 1-6 cells (Fig. 3C) and ghrelin-induced suppression of Leap2 expression was not significant in primary hepatocyte of GHSR-null mice

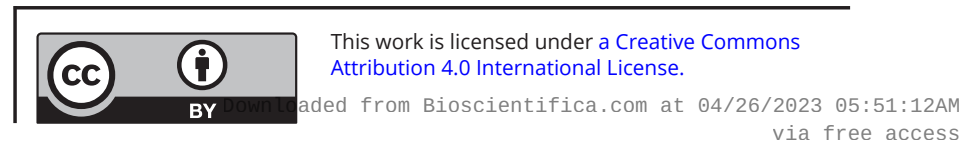



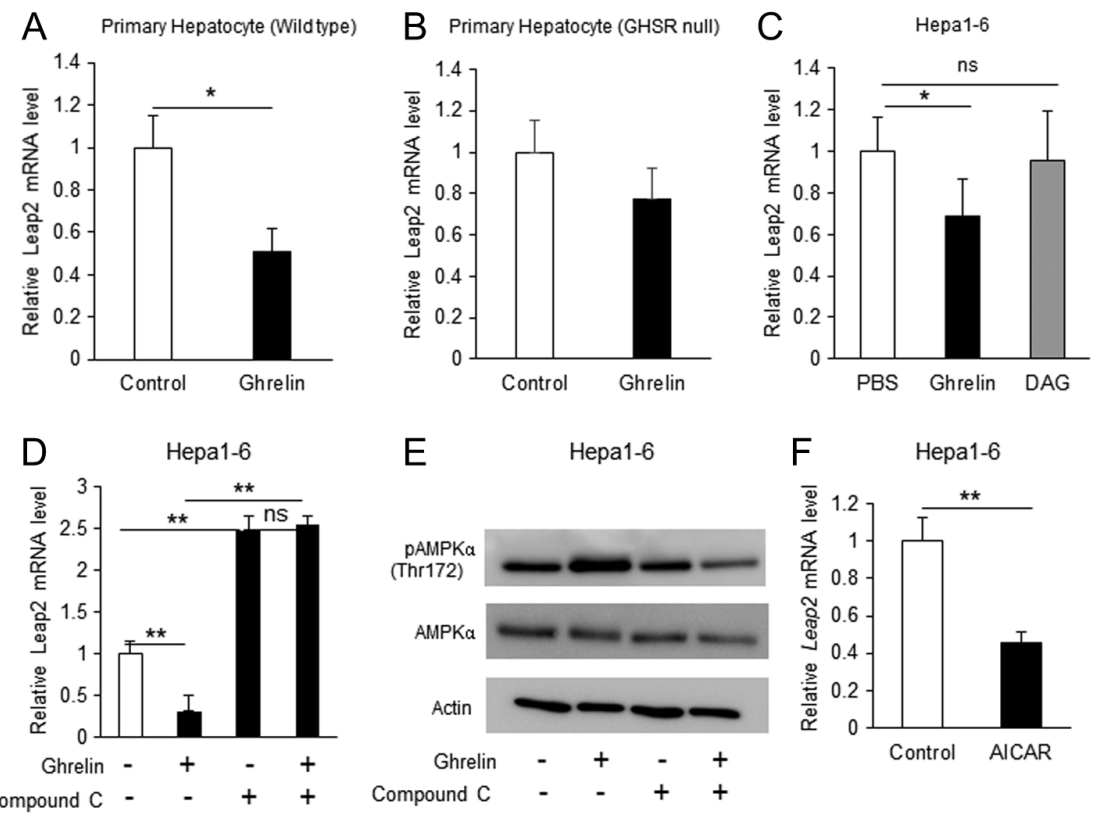

Figure 3

Ghrelin induces suppression of Leap2 expression through an AMPK-dependent pathway. (A) Ghrelin stimulation for $6 \mathrm{~h}$ decreased Leap2 mRNA in primary hepatocytes of WT mice $(n=5)$, but (B) not in primary hepatocyte of GHSR-null mice $(n=5)$. (C) In Hepa 1-6 cells, ghrelin but not des-acyl ghrelin (DAG) suppressed Leap2 mRNA expression ( $n=5$ ). (D) Compound C, an AMPK inhibitor, induced Leap2 mRNA and abolished ghrelin-induced suppression of Leap2 mRNA in Hepa 1-6 cells $(n=5)$. (E) Western blot analysis showing the impact of ghrelin on phosphorylated AMPK $\alpha$ (pAMPK $\alpha)(n=3)$. (F) Leap2 mRNA expression was decreased by AICAR, an AMPK activator $(n=5)$. Bars represent means \pm S.D. or S.E.M. $* P<0.05, * \star P<0.01$

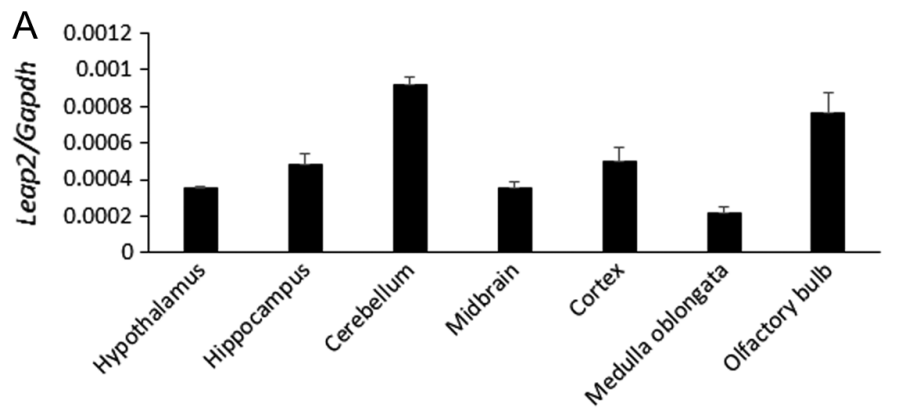

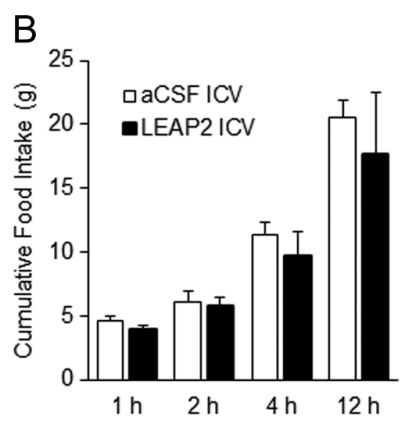
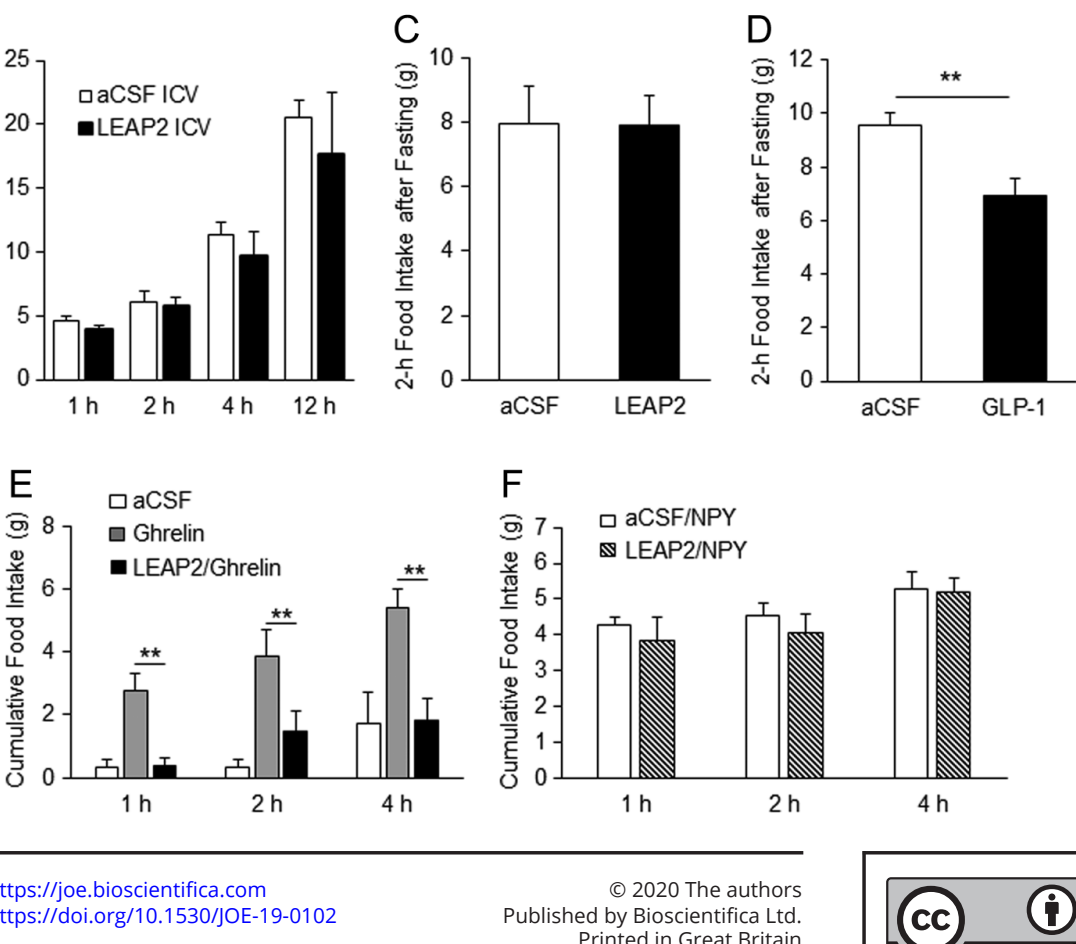

https://joe.bioscientifica.com https://doi.org/10.1530/JOE-19-0102
Published by Bioscientifica Ltd. Printed in Great Britain

\section{Figure 4}

i.c.v. administration of LEAP2 suppressed ghrelin-induced feeding in rats. (A) Leap2 expression in rat brain regions. i.c.v. administration of LEAP2 did not suppress (B) dark-phase food intake or (C) 14-h fasting-induced food intake. (D) GLP-1 suppressed fasting-induced feeding. LEAP2 suppressed (E) ghrelin-induced feeding but not (F) NPY-induced feeding $(n=4)$. Bars represent means \pm S.E.M. $* * P<0.01$.
This work is licensed under a Creative Commons Attribution 4.0 International License. 
(Fig. 3B). qRT-PCR cycle number for Ghsr mRNA was $33.2 \pm 0.2$ in primary mouse hepatocytes and $29.5 \pm 0.4$ in Hepa 1-6 cells. Next, we explored the pathway by which ghrelin suppresses Leap2 expression. An AMPK inhibitor compound $\mathrm{C}$ abolished ghrelin-induced suppression of Leap2 expression (Fig. 3D) and ghrelin-stimulated phosphorylation of AMPK (Fig. 3E) in Hepa 1-6 cells. Leap2 mRNA in Hepa 1-6 cells was decreased by AICAR, an AMPK activator (Fig. 3F).

\section{Central LEAP2 suppresses ghrelin-induced feeding}

Leap2 mRNA was expressed in various regions of rat brain (Fig. 4A). The activities of ghrelin are mediated through binding to the GHSR, which is expressed at high levels in the hypothalamic arcuate nucleus (ARC), dorsomedial hypothalamus (DMH), ventromedial hypothalamic nucleus (VMH), and lateral hypothalamic nucleus (LH) (Mitchell et al. 2001, Zigman et al. 2006). Hence, we investigated whether i.c.v. LEAP2 has any effects. i.c.v. administration of LEAP2 in the early dark-phase did not suppress dark-phase food intake (Fig. 4B). A similar effect was also observed in 14-h fasted rats (Fig. 4C), while central GLP-1 administration used as a positive control suppressed fasting-induced food intake (Fig. 4D).

Rats that received only ghrelin consumed significantly more food than control animals at 1, 2, and $4 \mathrm{~h}$ after single i.c.v. administration (Fig. 4E). This effect of ghrelin
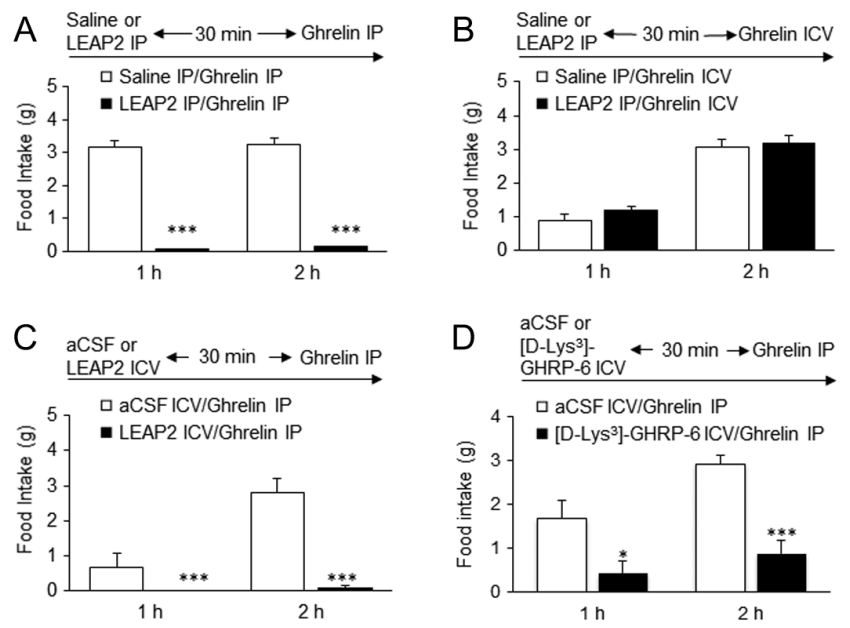

Figure 5

Effects of a combination of routes of administration of LEAP2 and ghrelin. i.p. LEAP2 administered $30 \mathrm{~min}$ before ghrelin administration suppressed the effect of i.p. ghrelin on feeding (A), but did not suppress i.c.v. ghrelin-induced feeding (B). i.p. ghrelin-induced feeding was suppressed by either i.c.v. LEAP2 (C) or i.c.v. [D-Lys3]-GHRP-6 administration 30 min beforehand $(D)(n=5)$. Bars represent means \pm S.E.M. $* P<0.05$; $* * * P<0.001$.
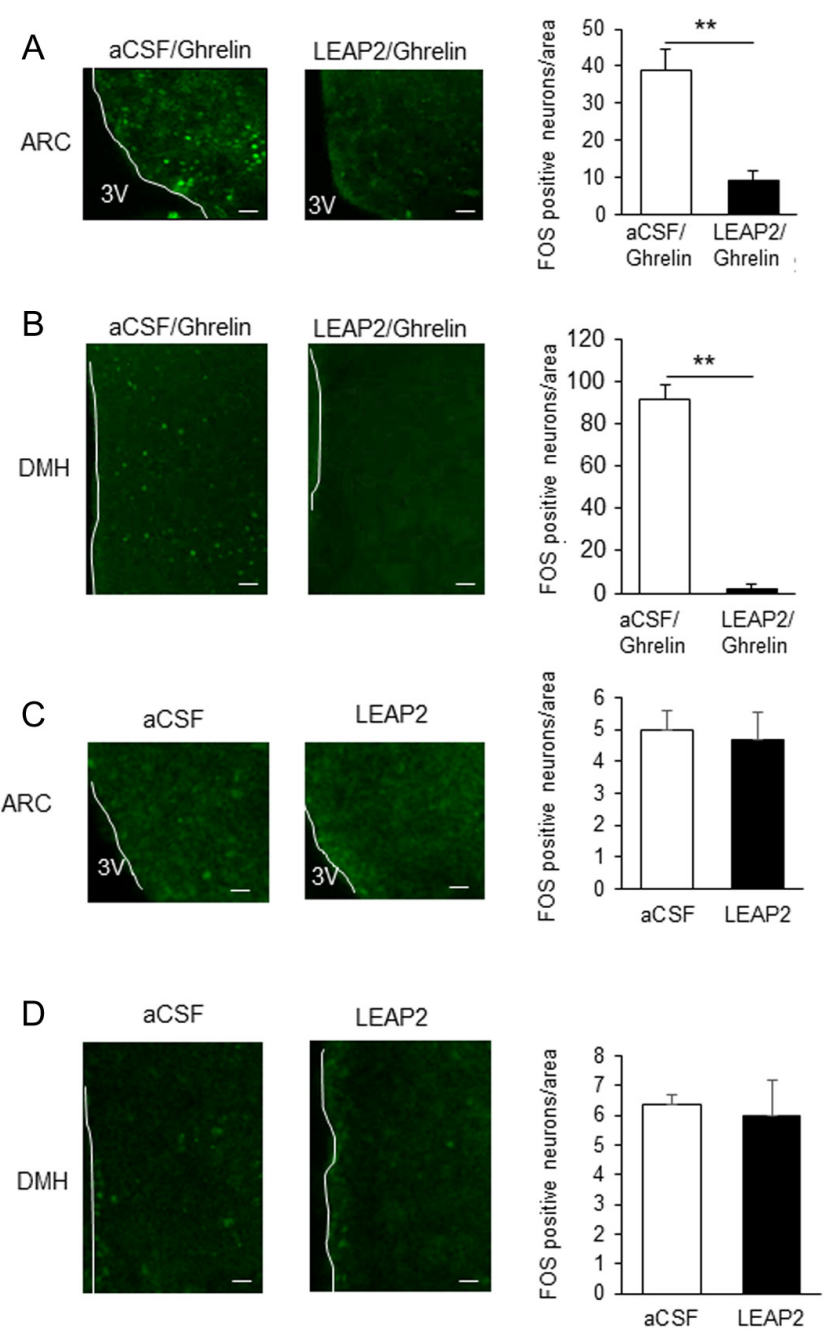

\section{Figure 6}

Fos expression in hypothalamic ARC and DMH. Fos expression was measured after i.c.v. administration of ghrelin with or without LEAP2 in ARC (A) and DMH (B) $(n=3)$. FOS expression was also measured after i.c.v. injection of vehicle aCSF or LEAP2 in ARC (C) and DMH (D). White line denotes the third ventricle (3V). Bars represent means \pm S.E.M. $* * P<0.01$. Scale bars, $50 \mu \mathrm{m}$.

was significantly eliminated by co-administration of i.c.v. LEAP2 (Fig. 4E). To investigate whether LEAP2 had any effect on the inhibition of NPY-induced food intake, we administered either NPY alone or NPY+LEAP2. Co-administration of LEAP2 with NPY did not suppress NPY-induced food intake (Fig. 4F).

We investigated whether LEAP2 and ghrelin would be effective when administered via a combination of routes. To carry out the combination study, we first administered LEAP2 intraperitoneally; $30 \mathrm{~min}$ later, we introduced ghrelin through the i.p. route, and then measured 1-h and 2-h food intake. At both time points, LEAP2 significantly suppressed ghrelin-induced

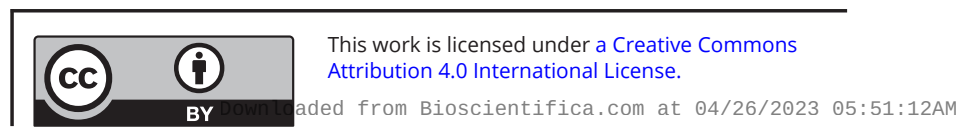



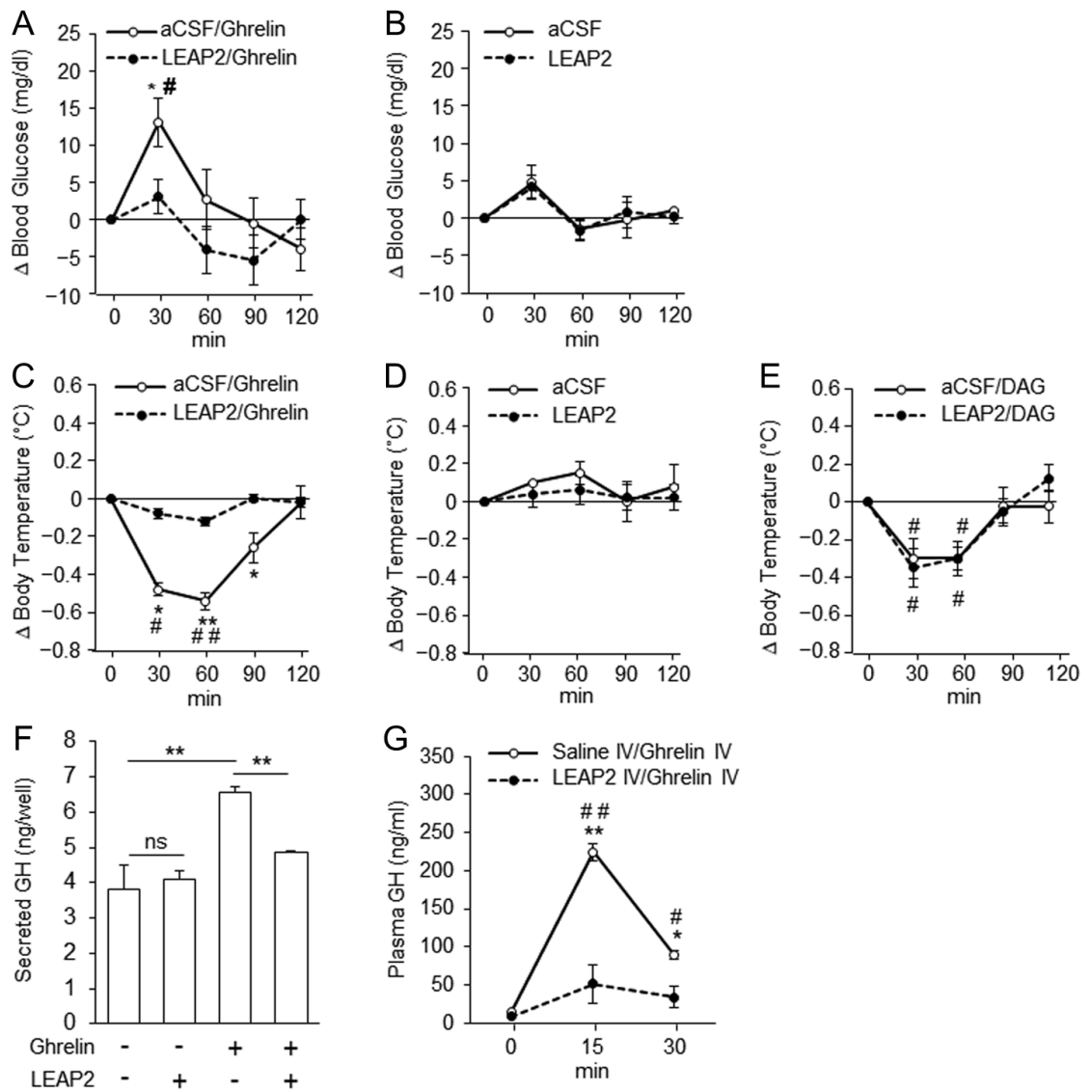

food intake (Fig. 5A). To determine whether peripheral LEAP2 could cancel the effect of central ghrelin, we performed another combination study in which we intraperitoneally administered LEAP2, and then centrally administered ghrelin 30 min later. LEAP2 did not abolish ghrelin-induced food intake (Fig. 5B). By contrast, i.c.v. administration of LEAP2 30 min beforehand abolished the effect of i.p. administration of ghrelin on feeding (Fig. 5C). i.c.v. administration of [D-Lys $\left.{ }^{3}\right]-G H R P-6$, a GHSR antagonist, also suppressed the effect of i.p. injection of ghrelin on feeding (Fig. 5D).

\section{LEAP2 suppresses ghrelin-induced Fos expression in rats}

Ghrelin-induced Fos expression in ARC and DMH was significantly suppressed by i.c.v. LEAP2 when co-administered with ghrelin (Fig. 6A and B). i.c.v. LEAP2 also suppressed i.p. ghrelin-induced Fos expression in ARC (Supplementary Fig. 2). But single i.c.v. administration of LEAP2 did not show any significant Fos expression in ARC and DMH compared with vehicle aCSF injection (Fig. $6 \mathrm{C}$ and $\mathrm{D})$.

\section{Figure 7}

Ghrelin-specific antagonistic effect of LEAP2. Blood glucose elevation was abolished by co-administration of LEAP2 and ghrelin (A and B) $(n=5)$. LEAP2 antagonized the effect of ghrelin, but not des-acyl ghrelin, on body temperature $\left(C_{\text {, }}\right.$ $\mathrm{D}$ and $\mathrm{E})(n=4)$. GH secretion from primary pituitary cells (F) $(n=4)$. GH secretion in rats (G) $(n=3)$. All data are presented as means \pm S.E.M. $\star P<0.05$ and ${ }^{*} * P<0.01$, between two groups; $\# P<0.05$ and $\# P<0.01$ vs 0 min.

\section{Antagonizing effects of LEAP2 on ghrelin-induced hyperglycemia, hypothermia and GH secretion}

i.c.v. administration of ghrelin significantly elevated blood glucose concentration (Fig. 7A). This elevation was abolished by co-administration of i.c.v. LEAP2 (Fig. 7A). However, a single i.c.v. administration of LEAP2 had no effect on blood glucose (Fig. 7B). i.c.v. administration of ghrelin rapidly decreased body temperature, which reached a nadir $60 \mathrm{~min}$ after the injection. This reduction was abolished by co-administration of i.c.v. LEAP2 (Fig. 7C). i.c.v. administration of LEAP2 did not change body temperature (Fig. 7D). To investigate whether LEAP2 had any effect on des-acyl ghrelin-induced reduction in body temperature, we co-administered des-acyl ghrelin and LEAP2. LEAP2 had no effect on des-acyl ghrelin-induced body temperature reduction (Fig. 7E). Both pituitary primary culture and in vivo experiments demonstrated that LEAP2 abolished the effect of ghrelin on GH secretion (Fig. 7F and G).

\section{Discussion}

In this study, we found that ghrelin regulated Leap2 mRNA expression in the liver, and that central administration

This work is licensed under a Creative Commons Attribution 4.0 International License. 
of LEAP2 abolished ghrelin-induced food intake, blood glucose elevation, and body temperature reduction. A previous study showed that peripheral administration of LEAP2 suppressed ghrelin-induced GH secretion and food intake in mice (Ge et al. 2018). Therefore, both central and peripheral LEAP2 antagonizes ghrelin functions.

Crosstalk between organs is important for maintenance of homeostasis. For example, feeding behavior is regulated by stomach-derived ghrelin which transfers the hunger signal to the hypothalamic arcuate nucleus via the vagus nerve (Yanagi et al. 2018), as well as by adipose tissue-derived protein leptin which also acts on the arcuate nucleus to suppress food intake (Friedman \& Halaas 1998). In the present study, the plasma concentration of LEAP2 exhibited dynamics opposite to that of ghrelin; that is, LEAP2 decreased upon fasting and increased upon re-feeding, as did Leap2 mRNA expression in the liver. Ghrelin administration to mice reduced the plasma concentration of LEAP2 and Leap2 mRNA in the liver. These findings suggest that the concentration of plasma LEAP2 depends on the hepatic Leap2 expression. Ghrelin administration did not suppress plasma LEAP2 or Leap2 mRNA in the liver of GHSR-null mice which is further supported by the in vitro study in the primary hepatocyte of GHSR-null mice. Both plasma LEAP2 and Leap2 mRNA expression in the liver of GHSR-null mice were not significantly differing than those of WT mice. The documented effects of ghrelin on feeding and GH release suggested that lack of ghrelinGHSR signaling might affect the normal feeding and growth. Interestingly, GHSR-null mice did not show any significant difference in term of food intake, body weight and growth than those of their WT littermates (Sun et al. 2004, Zigman et al. 2005). Moreover, serum ghrelin, leptin and insulin levels were not significantly different between the two genotypes, both fed and fasting state (Sun et al. 2004). Combined with the result indicating no effect of des-acyl ghrelin on Leap2 mRNA in Hepa 1-6 cells, ghrelin's suppressive effect on Leap2 expression was dependent on GHSR. We detected GHSR mRNA expression in both Hepa 1-6 and in the mouse liver. Although GHSR expression in the liver was low, it was enough for ghrelin to act on Leap2 expression in the liver, as ghrelin was ineffective to suppress Leap2 expression in the liver of GHSR-null mice, in both in vitro and in vivo. Chuang et al. reported that Ghsr expression depends on ambient glucose with high glucose suppress Ghsr expression (Chuang et al. 2011). The study implied condition dependent Ghsr expression in the liver which was profound under fasting state when blood glucose level became low. A previous study showed that ghrelin induced AMPK phosphorylation in rat hepatocytes (Ezquerro et al. 2016), and we here confirmed this finding in Hepa 1-6 cells. Phosphorylated AMPK suppresses the activity of sterol regulatory element-binding protein 1 (SREBP1), a key transcription factor involved in the regulation of lipid metabolism (Li et al. 2011). The binding consensus sequence of SREBP1 is present in the promoter region of Leap2. Leap2 expression level may be regulated by the ghrelin-AMPK-SREBP1 pathway in the liver. This suggests that ghrelin affects feeding and energy homeostasis not only through the stomach-brain axis, but also through the stomach-liver axis.

Ghrelin binds to GHSR and promotes feeding by increasing expression of NPY and AgRP, hypothalamic downstream mediators of the GHSR pathway (Willesen et al. 1999, Nakazato et al. 2001). Ghrelin-induced feeding is canceled not only by inhibitors of GHSR, but also by neutralizing antibody against NPY and antagonists for NPY Y1 and Y5 receptors (Nakazato et al. 2001). We found that LEAP2 did not suppress NPY-induced feeding, suggesting that NPY is not a target of LEAP2. Both acyl ghrelin and des-acyl ghrelin decrease body temperature in rats (Lawrence et al. 2002, Inoue et al. 2013), whereas desacyl ghrelin has been thought to have specific receptor other than GHSR (Sato et al. 2006, Lear et al. 2010). Consistent with this, LEAP2 did not suppress des-acyl ghrelin-induced reduction in body temperature. Together, these results imply that LEAP2 targets GHSR.

Recently published two articles on LEAP2 research demonstrated that entire sequence of LEAP2 peptide was not necessary to bind to its target receptor GHSR (M'Kadmi et al. 2019, Wang et al. 2019). Indeed, N-terminal region of the LEAP2 peptide exhibited inverse agonist activity toward the GHSR and was able to inhibit subcutaneous ghrelin-induced food intake in mice (M'Kadmi et al. 2019). In contrast, Ge et al. reported LEAP2 as a noncompetitive antagonist to the GHSR (Ge et al. 2018). Interestingly, another form of LEAP2 peptide (44-77) lacking N-terminal region was found in the circulation which did not display antimicrobial activity. But two disulfide bonds are necessary for the stabilization of the LEAP2 peptide (Krause et al. 2003). This implies that N-terminal region of the LEAP2 peptide may facilitate for the binding and core region containing two disulfide bonds are crucial for the stability of the peptide. However, further study is needed to investigate the nature of action of N-terminal LEAP2 toward GHSR. It is also necessary to investigate whether this short fragment of LEAP2 peptide is stable at in vivo condition or whether it exhibits inhibitory effects of ghrelin action besides feeding behavior, for example, on ghrelin-induced GH release.

This work is licensed under a Creative Commons Attribution 4.0 International License. 
Ghrelin acts directly on the pituitary gland to induce GH secretion (Kojima et al. 1999). We previously reported that GHSR mRNA expressed in vagal nodose ganglion and binding of radiolabeled ghrelin in the vagus nerve (Date et al. 2002) Bilateral subdiaphragmatic vagotomy, selective gastric branch vagotomy, or perivagal capsaicin injection blocked the feeding stimulatory effects of i.v. ghrelin in rats (Date et al. 2002) and bilateral subdiaphragmatic vagotomy blocked the i.p. ghrelin-induced feeding in mice (Asakawa et al. 2001). Moreover, intravenous ghrelin infusion failed to increase feeding in human after bilateral subdiaphragmatic vagotomy and lower esophageal or gastric surgery (Ie Roux et al. 2005). Consistent with the vagal involvement in the feeding stimulatory effects of ghrelin, ghrelin also decreased vagal afferent activity in rats and an intact vagal afferent nerve activity is required to induce i.v. but not i.c.v. ghrelin-induced Fos expression in the ARC (Date et al. 2002). i.c.v. ghrelin induces the Fos expression in various brain regions but peripheral ghrelin induces the hypothalamic ARC Fos expression only (Hewson et al. 2000, Nakazato et al. 2001, Date et al. 2002, Cabral et al. 2014). Thus, a divergent pattern of Fos expression is observed by central or peripheral ghrelin administration. However, GHSR expression in vagal nodose ganglion is necessary to exhibit the ghrelininduced food intake (Okada et al. 2018). On the other hand, ghrelin crosses the blood-brain barrier from bloodto-brain and from brain-to-blood in a saturated transport system (Banks et al. 2002, Rhea et al. 2018, Banks 2019). Ghrelin in CSF is accessible to the most areas of the brain where GHSR is expressed abundantly (Cabral et al. 2013) and centrally administered GHSR antagonist abolished the peripherally ghrelin-induced feeding (Asakawa et al. 2003). Together, these reports indicate that both vagal nerve innervation and direct activation of brain GHSR by peripheral ghrelin are required to display ghrelininduced food intake. It remains unclear how LEAP2 expression is regulated in the brain and whether LEAP2 can cross the blood-brain barrier. We here showed that both i.c.v. LEAP2 and i.c.v. [D-Lys ${ }^{3}$ ]-GHRP-6 inhibited i.p. ghrelin-induced feeding and Fos expression in the ARC. These results suggest that GHSR activation in the brain is required for ghrelin-induced feeding when administered peripherally. LEAP2 administration to isolated pituitary glands suppressed ghrelin-induced GH secretion, whereas peripheral LEAP2 did not impact i.c.v. ghrelin-induced food intake. In addition, peripheral administration of a neutralizing antibody against LEAP2 increased GH secretion (Ge et al. 2018). These findings suggest that LEAP2 in the brain acts on pituitary to suppress GH secretion. The regulation of LEAP2 expression in the brain is important to understand central ghrelin functions.

In conclusion, our results demonstrate that ghrelin and LEAP2 cooperate to regulate feeding and energy homeostasis through two mechanisms: crosstalk between stomach and liver, and direct inhibition of peripheral and central GHSR by LEAP2. LEAP2 agonism represents a possible therapeutic target for obesity and diabetes, and LEAP2 antagonism for anorexia and cancer cachexia. Further study is needed to investigate the efficacy and safety of LEAP2 as a treatment for these diseases.

\section{Supplementary materials}

This is linked to the online version of the paper at https://doi.org/10.1530/ JOE-19-0102.

\section{Declaration of interest}

The authors declare that they have no conflict of interest that could be perceived as prejudicing the impartiality of the research reported.

\section{Funding}

This research was supported by JSPS KAKENHI (No. 16H05333) and AMEDCREST (No. JP18gm0610016) to M N

\section{Author contribution statement}

Y M, H S, and M N designed the experiments; $\mathrm{M} \mathrm{N} \mathrm{I,} \mathrm{Y} \mathrm{M,} \mathrm{R} \mathrm{T,} \mathrm{W} \mathrm{Z} \mathrm{and} \mathrm{K} \mathrm{M}$ performed the experiments; and $\mathrm{M} \mathrm{N} \mathrm{I,} \mathrm{Y} \mathrm{M,} \mathrm{R} \mathrm{T,} \mathrm{W} \mathrm{Z} \mathrm{and} \mathrm{K} \mathrm{M}$ analyzed the data. All authors prepared and approved the final version of the manuscript.

\section{Acknowledgments}

The authors thank Koji Toshinai (Shigakukan University), Hiroshi Hosoda, and Morikatsu Yoshida (National Cerebral and Cardiovascular Center Research Institute) for their excellent technical assistance and helpful discussion.

\section{References}

Ariyoshi K, Fujishima Y, Miura T, Shang Y, Kakinuma S, Yoshiya S, Kasai K, Nakata A, Tachibana A \& Yoshida MA 2017 Rapid isolation of murine primary hepatocytes for chromosomal analysis. In Vitro Cellular and Developmental Biology - Animal 53 474-478. (https://doi. org/10.1007/s11626-017-0132-7)

Asakawa A, Inui A, Kaga T, Yuzuriha H, Nagata T, Ueno N, Makino S, Fujimiya M, Niijima A, Fujino MA, et al. 2001 Ghrelin is an appetitestimulatory signal from stomach with structural resemblance to motilin. Gastroenterology 120 337-345. (https://doi.org/10.1053/gast.2001.22158)

Asakawa A, Inui A, Kaga T, Katsuura G, Fujimiya M, Fujino MA \& Kasuga M 2003 Antagonism of ghrelin receptor reduces food intake and body weight gain in mice. Gut 52 947-952. (https://doi. org/10.1136/gut.52.7.947)

Banks WA 2019 The blood-brain barrier as an endocrine tissue. Nature Reviews Endocrinology 15 444-455. (https://doi.org/10.1038/s41574019-0213-7)

Banks WA, Tschöp M, Robinson SM \& Heiman ML 2002 Extent and direction of ghrelin transport across the blood-brain barrier is determined by its unique primary structure. Journal of Pharmacology and Experimental Therapeutics 302 822-827. (https://doi.org/10.1124/ jpet.102.034827) 
Cabral A, Fernandez G \& Perello M 2013 Analysis of brain nuclei accessible to ghrelin present in the cerebrospinal fluid. Neuroscience 253 406-415. (https://doi.org/10.1016/j.neuroscience.2013.09.008)

Cabral A, Valdivia S, Fernandez G, Reynaldo M \& Perello M 2014 Divergent neuronal circuitries underlying acute orexigenic effects of peripheral or central ghrelin: critical role of brain accessibility. Journal of Neuroendocrinology 26 542-554. (https://doi.org/10.1111/jne.12168)

Chuang JC, Sakata I, Kohno D, Perello M, Osborne-Lawrence S, Repa JJ \& Zigman JM 2011 Ghrelin directly stimulates glucagon secretion from pancreatic alpha-cells. Molecular Endocrinology 25 1600-1611. (https:// doi.org/10.1210/me.2011-1001)

Date Y, Murakami N, Toshinai K, Matsukura S, Niijima A, Matsuo H, Kangawa K \& Nakazato M 2002 The role of the gastric afferent vagal nerve in ghrelin-induced feeding and growth hormone secretion in rats. Gastroenterology 123 1120-1128. (https://doi.org/10.1053/ gast.2002.35954)

Ezquerro S, Méndez-Giménez L, Becerril S, Moncada R, Valentí V, Catalán V, Gómez-Ambrosi J, Frühbeck G \& Rodríguez A 2016 Acylated and desacyl ghrelin are associated with hepatic lipogenesis, $\beta$-oxidation and autophagy: role in NAFLD amelioration after sleeve gastrectomy in obese rats. Scientific Reports 6 39942. (https://doi.org/10.1038/srep39942)

Friedman JM \& Halaas JL 1998 Leptin and the regulation of body weight in mammals. Nature 395 763-770. (https://doi.org/10.1038/27376)

Ge X, Yang H, Bednarek MA, Galon-Tilleman H, Chen P, Chen M, Lichtman JS, Wang Y, Dalmas O, Yin Y, et al. 2018 LEAP2 is an endogenous antagonist of the ghrelin receptor. Cell Metabolism 27 461-469.e6. (https://doi.org/10.1016/j.cmet.2017.10.016)

Hewson AK \& Dickson SL 2000 Systemic administration of ghrelin induces fos and egr-1 proteins in the hypothalamic arcuate nucleus of fasted and fed rats. Journal of Neuroendocrinology 12 1047-1049. (https://doi.org/10.1046/j.1365-2826.2000.00584.X)

Inoue Y, Nakahara K, Maruyama K, Suzuki Y, Hayashi Y, Kangawa K \& Murakami N 2013 Central and peripheral des-acyl ghrelin regulates body temperature in rats. Biochemical and Biophysical Research Communications 430 278-283. (https://doi.org/10.1016/j. bbrc.2012.10.137)

Kojima M, Hosoda H, Date Y, Nakazato M, Matsuo H \& Kangawa K 1999 Ghrelin is a growth-hormone-releasing acylated peptide from stomach. Nature 402 656-660. (https://doi.org/10.1038/45230)

Krause A, Neitz S, Mägert HJ, Schulz A, Forssmann WG, Schulz-Knappe P \& Adermann K 2000 LEAP-1, a novel highly disulfidebonded human peptide, exhibits antimicrobial activity. FEBS Letters 480 147-150. (https://doi.org/10.1016/S0014-5793(00)01920-7)

Krause A, Sillard R, Kleemeier B, Klüver E, Maronde E, Conejo-García JR, Forssmann WG, Schulz-Knappe P, Nehls MC, Wattler F, et al. 2003 Isolation and biochemical characterization of LEAP-2, a novel blood peptide expressed in the liver. Protein Science 12 143-152. (https://doi. org/10.1110/ps.0213603)

Lawrence CB, Snape AC, Baudoin FM-H \& Luckman SM 2002 Acute central ghrelin and GH secretagogues induce feeding and activate brain appetite centers. Endocrinology 143 155-162. (https://doi. org/10.1210/endo.143.1.8561)

Lear PV, Iglesias MJ, Feijóo-Bandín S, Rodríguez-Penas D, MosqueraLeal A, García-Rúa V, Gualillo O, Ghè C, Arnoletti E, Muccioli G, et al. 2010 Des-acyl ghrelin has specific binding sites and different metabolic effects from ghrelin in cardiomyocytes. Endocrinology 151 3286-3298. (https://doi.org/10.1210/en.2009-1205)

le Roux CW, Neary NM, Halsey TJ, Small CJ, Martinez-Isla AM, Ghatei MA, Theodorou NA \& Bloom SR 2005 Ghrelin does not stimulate food intake in patients with surgical procedures involving vagotomy. Journal of Clinical Endocrinology and Metabolism 90 4521-4524. (https://doi.org/10.1210/jc.2004-2537)
Li Y, Xu S, Mihaylova MM, Zheng B, Hou X, Jiang B, Park O, Luo Z, Lefai E, Shyy JY-J, et al. 2011 AMPK phosphorylates and inhibits SREBP activity to attenuate hepatic steatosis and atherosclerosis in diet-induced insulin-resistant mice. Cell Metabolism 13 376-388. (https://doi.org/10.1016/j.cmet.2011.03.009)

M'Kadmi C, Cabral A, Barrile F, Giribaldi J, Cantel S, Damian M, Mary S, Denoyelle S, Dutertre S, Péraldi-Roux S, et al. 2019 N-terminal liverexpressed antimicrobial peptide 2 (LEAP2) region exhibits inverse agonist activity toward the ghrelin receptor. Journal of Medicinal Chemistry 62 965-973. (https://doi.org/10.1021/acs.jmedchem.8b01644)

Mita Y, Nakayama K, Inari S, Nishito Y, Yoshioka Y, Sakai N, Sotani K, Nagamura T, Kuzuhara Y, Inagaki K, et al. 2017 Selenoprotein P-neutralizing antibodies improve insulin secretion and glucose sensitivity in type 2 diabetes mouse models. Nature Communications $\mathbf{8}$ 1658. (https://doi.org/10.1038/s41467-017-01863-z)

Mitchell V, Bouret S, Beauvillain JC, Schilling A, Perret M, Kordon C \& Epelbaum J 2001 Comparative distribution of mRNA encoding the growth hormone secretagogue-receptor (GHS-R) in Microcebus murinus (Primate, lemurian) and rat forebrain and pituitary. Journal of Comparative Neurology 429 469-489. (https://doi.org/10.1002/10969861(20010115)429:3<469::aid-cne8>3.0.co;2-\#)

Nakazato M, Murakami N, Date Y, Kojima M, Matsuo H, Kangawa K \& Matsukura S 2001 A role for ghrelin in the central regulation of feeding. Nature 409 194-198. (https://doi.org/10.1038/35051587)

Okada T, Waise TMZ, Toshinai K, Mita Y, Sakoda H \& Nakazato M 2018 Analysis of peripheral ghrelin signaling via the vagus nerve in ghrelin receptor-restored GHSR-null mice. Neuroscience Letters 681 50-55. (https://doi.org/10.1016/j.neulet.2018.05.035).

Rhea EM, Salameh TS, Gray S, Niu J, Banks WA \& Tong J 2018 Ghrelin transport across the blood-brain barrier can occur independently of the growth hormone secretagogue receptor. Molecular Metabolism 18 88-96. (https://doi.org/10.1016/j.molmet.2018.09.007)

Sato M, Nakahara K, Goto S, Kaiya H, Miyazato M, Date Y, Nakazato M, Kangawa K \& Murakami N 2006 Effects of ghrelin and des-acyl ghrelin on neurogenesis of the rat fetal spinal cord. Biochemical and Biophysical Research Communications 350 598-603. (https://doi. org/10.1016/j.bbrc.2006.09.088)

Sun Y, Wang P, Zheng H \& Smith RG 2004 Ghrelin stimulation of growth hormone release and appetite is mediated through the growth hormone secretagogue receptor. PNAS 101 4679-4684. (https://doi. org/10.1073/pnas.0305930101)

Wang JH, Li HZ, Shao XX, Nie WH, Liu YL, Xu ZG \& Guo ZY 2019 Identifying the binding mechanism of LEAP 2 to receptor GHSR1a. FEBS Journal 286 1332-1345. (https://doi.org/10.1111/febs.14763)

Willesen MG, Kristensen P \& Rømer J 1999 Co-localization of growth hormone secretagogue receptor and NPY mRNA in the arcuate nucleus of the rat. Neuroendocrinology 70 306-316. (https://doi. org/10.1159/000054491)

Wren AM, Seal LJ, Cohen MA, Brynes AE, Frost GS, Murphy KG, Dhillo WS, Ghatei MA \& Bloom SR 2001 Ghrelin enhances appetite and increases food intake in humans. Journal of Clinical Endocrinology and Metabolism 86 5992. (https://doi.org/10.1210/jcem.86.12.8111)

Yanagi S, Sato T, Kangawa K \& Nakazato M 2018 The homeostatic force of ghrelin. Cell Metabolism 27 786-804. (https://doi.org/10.1016/j. cmet.2018.02.008)

Zigman JM, Nakano Y, Coppari R, Balthasar N, Marcus JN, Lee CE, Jones JE, Deysher AE, Waxman AR, White RD, et al. 2005 Mice lacking ghrelin receptors resist the development of diet-induced obesity. Journal of Clinical Investigation 115 3564-3572. (https://doi.org/10.1172/JCI26002)

Zigman JM, Jones JE, Lee CE, Saper CB \& Elmquist JK 2006 Expression of ghrelin receptor mRNA in the rat and the mouse brain. Journal of Comparative Neurology 494 528-548. (https://doi.org/10.1002/cne.20823)

Received in final form 13 September 2019

Accepted 19 September 2019

Accepted Manuscript published online 19 September 2019 https://joe.bioscientifica.com https://doi.org/10.1530/JOE-19-0102 (c) 2020 The authors Published by Bioscientifica Ltd. Printed in Great Britain

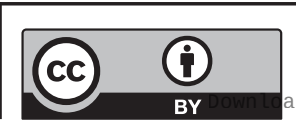

This work is licensed under a Creative Commons Attribution 4.0 International License. 